\title{
Grifolic acid induces mitochondrial membrane potential loss and cell death of RAW264.7 macrophages
}

\author{
YUFENG ZHAO $^{1 *}$, HAI ZHANG ${ }^{2 *}$, AILI YAN ${ }^{1}$, JUANXIA ZHU $^{1}$, KE LIU $^{1}$, \\ DI CHEN ${ }^{1}$, RONG XIE ${ }^{1}, \mathrm{XI} \mathrm{XU}^{1}$ and XINGLI SU ${ }^{1}$ \\ ${ }^{1}$ Institute of Basic Medical Sciences, Xi'an Medical University, Xi'an, Shaanxi 710021; \\ ${ }^{2}$ Laboratory Animal Center, Fourth Military Medical University, Xi'an, Shaanxi 710032, P.R. China
}

Received November 9, 2016; Accepted November 13, 2017

DOI: $10.3892 / \mathrm{mmr} .2017 .8218$

\begin{abstract}
Grifolic acid is a phenolic compound that was first extracted from the mushroom Albatrellus confluens; it acts as an agonist of the free fatty acid receptor (FFAR4). FFAR4 is expressed in macrophages and mediates the anti-inflammatory effects of n-3 unsaturated free fatty acids. In the present study, the effects of grifolic acid on macrophages were observed in mouse RAW264.7 cells. It was demonstrated that grifolic acid (2.5-20 $\mu \mathrm{mol} / \mathrm{l})$ treatment reduced RAW264.7 cell viability in a dose- and time-dependent manner. The number of apoptotic cells significantly increased following grifolic acid treatment compared with the untreated control cells. Grifolic acid treatment resulted in a significant decrease in cellular adenosine 5'-triphosphate (ATP) content in RAW264.7 cells. Mitochondrial membrane potential (MMP), as measured by JC-1 staining, was significantly diminished by grifolic acid treatment in a dose- and time-dependent manner. Treatment with cyclosporine A, a protector of MMP, attenuated grifolic acid-induced reduction of MMP and viability in RAW264.7 cells. FFAR4 knockdown did not significantly influence grifolic acid-induced reduction of cell viability, ATP levels or MMP. In conclusion, grifolic acid may induce macrophage cell death by reducing MMP and by inhibiting ATP production probably in an FFAR4-independent manner.
\end{abstract}

\section{Introduction}

Free fatty acid receptor 4 (FFAR4) is activated by long chain free fatty acids (FFAs), and its activation serves diverse roles

Correspondence to: Professor Xingli Su or Professor Xi Xu, Institute of Basic Medical Sciences, Xi'an Medical University, 1 Xinwang Road, Xi'an, Shaanxi 710021, P.R. China

E-mail: xingli_su@163.com

E-mail: 511685623@qq.com

${ }^{*}$ Contributed equally

Key words: grifolic acid, macrophage, mitochondria, cell death, free fatty acid receptor 4 in regulating hormone secretion, inflammatory responses and cell survival (1-3). Previous studies that examined the functions of FFAR4 identified a series of non-FFA agonists, and among them was grifolic acid $(2,4,5)$. Grifolic acid is a phenolic compound that was initially isolated from the fruiting bodies of the mushroom Albatrellus confluens. The pharmacological actions of grifolic acid have not been fully characterized, except for its ability to activate FFAR4. Grifolic acid was reported to activate extracellular signal-regulated kinase (ERK) responses and to stimulate an increase in intracellular calcium concentrations $\left[\left(\mathrm{Ca}^{2+}{ }_{\mathrm{i}}\right)\right]$ in FFAR4-expressing cells, but not in FFAR1-expressing cells (2). In addition, grifolic acid exhibited stimulatory effects on glucagon-like peptide-1 secretion in mouse enteroendocrine STC-1 cells that express FFAR4 endogenously $(2,6)$. Conversely, grifolic acid inhibited the $\alpha$-linolenic acid-induced ERK and $\left[\mathrm{Ca}^{2+}\right]_{\mathrm{i}}$ responses in FFAR4-expressing cells (2). Grifolic acid was also revealed to attenuate lard oil-induced secretion of glucose-dependent insulinotropic polypeptide (GIP) from FFAR4-expressing $\mathrm{K}$ cells of the upper small intestine (7).

FFAR4 is expressed in pro-inflammatory CD11c ${ }^{+}$ macrophages, in mouse RAW264.7 macrophages and in primary intraperitoneal macrophages (8). FFAR4 activation was previously reported to inhibit the lipopolysaccharide (LPS)-stimulated phosphorylation of inhibitor of nuclear factor- $\kappa \mathrm{B}$ kinase subunit $\beta$ and $\mathrm{c}$-Jun $\mathrm{N}$-terminal kinase and subsequently inhibited the secretion of tumor necrosis factor- $\alpha$ and interleukin (IL)-6 in RAW264.7 cells (8). Another previous study demonstrated that FFAR4 activation promoted the actions of cytosolic phospholipase A2 and cyclooxygenase-2 in RAW264.7 cells and in human primary monocyte-derived macrophages, which in turn led to prostaglandin $E_{2}$ release, nuclear factor $(N F)-\kappa B$ inhibition and the inhibition of LPS-induced IL-6 secretion (9). Therefore, it is clear that FFAR4 is expressed in macrophages and has anti-inflammatory effects; however, the effects of grifolic acid on the function of macrophages remain unknown. In the present study, the effects of grifolic acid on macrophages were investigated and an FFAR4-independent function was identified. These finding demonstrated a novel action of grifolic acid on cells, and it is recommended that care should be taken when grifolic acid is used as FFAR4 agonist. 


\section{Materials and methods}

Chemicals. Grifolic acid was obtained from R\&D Systems Inc. (Minneapolis, MN, USA). Rabbit anti-FFAR4 polyclonal antibody (cat. no. SAB4501490) and cellular adenosine 5'-triphosphate (ATP) assay kit were purchased from Sigma-Aldrich (Merck KGaA; Darmstadt, Germany). Annexin V-fluorescein isothiocyanate (FITC)/propidium iodide (PI) staining kits were purchased from BD Pharmingen (BD Biosciences, San Jose, CA, USA). Mouse FFAR4 Silencer Select siRNA (cat. no. S200889), Silencer Negative Control siRNA (cat. no. AM4613), Lipofectamine ${ }^{\circledR}$ RNAiMAX reagent, Opti-MEM medium, Dulbecco's modified Eagle's medium (DMEM), fetal bovine serum (FBS), JC-1 dye and rabbit anti-b-actin polyclonal antibody (cat. no. PA1-183) were purchased from Thermo Fisher Scientific, Inc. (Waltham, MA, USA).

Cell culture. Mouse RAW264.7 cells were purchased from ATCC (Manassas, VA, USA) and cultured in a humidified incubator with $5 \% \mathrm{CO}_{2}$ at $37^{\circ} \mathrm{C}$ in DMEM supplemented with $10 \% \mathrm{FBS}, 100 \mathrm{U} / \mathrm{ml}$ penicillin and $100 \mu \mathrm{g} / \mathrm{ml}$ streptomycin. The medium was changed every 3 days, and RAW264.7 cells were subcultured at $80 \%$ confluency and seeded to plates or dishes for each experiment.

Cell viability assay. RAW264.7 cells were cultured in 96-well plates and treated with grifolic acid (1.25-20 $\mu \mathrm{mol} / 1$ for $2-24 \mathrm{~h}$ at $37^{\circ} \mathrm{C}$ ) at $90 \%$ confluency in serum-free medium. The control cells were treated with the solvent without grifolic acid. Subsequently, MTT was added into medium $(0.5 \mathrm{mg} / \mathrm{ml})$ and cells were incubated for $4 \mathrm{~h}$ at $37^{\circ} \mathrm{C}$. The medium was discarded and $100 \mu 1$ isopropanol with $0.01 \mathrm{M} \mathrm{HCl}$ was added to each well and plates were agitated to fully dissolve MTT crystals. The absorbance of each well was measured at $560 \mathrm{~nm}$ with an ELISA microplate reader (Thermo Fisher Scientific, Inc.). The background absorbance at $690 \mathrm{~nm}$ was also measured and subtracted from the values measured at $560 \mathrm{~nm}$. The experiments were repeated three times.

Flow cytometry. The Annexin V-FITC/PI Apoptosis Detection kit was used to measure cell death. Following incubation with $0 \mu \mathrm{mol} / 1$ (control), 10 or $20 \mu \mathrm{mol} / 1$ grifolic acid, RAW264.7 cells were detached from dishes by $0.05 \%$ trypsin/EDTA. Cells were washed with cold PBS and resuspended in the binding buffer supplied in the kit at $1 \times 10^{6} \mathrm{cells} / \mathrm{ml}$. Annexin V-FITC and PI were added to cell suspension at a dilution of 1:20 and incubated for $15 \mathrm{~min}$ at room temperature in the dark. Subsequently, cells were diluted in binding buffer and analyzed by flow cytometry with the CFlow Plus software (BD Biosciences), and the $\mathrm{FITC}^{+} / \mathrm{PI}^{+}$double-positive cells were counted. The experiments were repeated three times.

Cellular ATP content measurement. RAW264.7 cells ( $1 \times 10^{7}$ cells per sample) were treated with grifolic acid (10 or $20 \mu \mathrm{mol} / 1$ for $2 \mathrm{~h}$ ). Subsequently, cells were lysed and intracellular ATP levels were measured using ATP assay kits (Sigma-Aldrich; Merck KGaA). Briefly, cell lysates from different groups were obtained by incubating with detergent and agitation at $\sim 12 \mathrm{~Hz}$ for $5 \mathrm{~min}$ at room temperature. The constituted substrate solutions given in the kits were added to each sample and incubated for $5 \mathrm{~min}$ in the dark. The luminescence of each sample was measured with a luminescence plate reader (Thermo Fisher Scientific, Inc.). ATP levels of each sample were calculated according to the constructed standard curve. The total protein of each sample was extracted using the radioimmunoprecipitation lysis buffer from the Beyotime Institute of Biotechnology (Beijing, China) and quantified by bicinchoninic acid (BCA) assay. The cellular ATP content was corrected to the total protein levels. The experiments were repeated three times.

Measurement of mitochondrial membrane potential (MMP). RAW264.7 cells $\left(5 \times 10^{5}\right.$ cells/well) were plated into $35 \mathrm{~mm}$ dishes and stained with JC-1 $(5 \mu \mathrm{g} / \mathrm{ml})$ in serum-free medium for $15 \mathrm{~min}$ at $37^{\circ} \mathrm{C}$. Subsequently, cells were washed with serum-free medium, and the fluorescence was recorded prior to $(0 \mathrm{~min})$ and following grifolic acid treatment every 10 min using a Leica TCS SP8 confocal microscope (Leica Microsystems, Inc., Buffalo Grove, IL, USA) in live cell station at $37^{\circ} \mathrm{C}$. For cyclosporine A treatment, the cells were incubated with $20 \mu \mathrm{mol} / \mathrm{l}$ cyclosporine A for $10 \mathrm{~min}$ prior to stimulation with grifolic acid. The red fluorescence (excitation $560 \mathrm{~nm}$; emission $600 \mathrm{~nm}$ ) and green fluorescence (excitation $488 \mathrm{~nm}$; emission $535 \mathrm{~nm}$ ) were measured synchronously, and the ratio of fluorescence intensity for each cell was analyzed by LAS LITE version 3.3 (Leica Microsystems, Inc., Buffalo Grove, IL, USA). The experiments were repeated three times.

FFAR4 siRNA transfection. RAW264.7 cells were grown to $80 \%$ confluency at the time of transfection. The mouse FFAR4 siRNA (100 pmol, Thermo Fisher Scientific, Inc.) or negative control siRNA (100 pmol; Thermo Fisher Scientific, Inc. was diluted in $50 \mu \mathrm{l}$ Opti-MEM medium (Thermo Fisher Scientific, Inc.), and Lipofectamine RNAiMAX ( $1 \mu \mathrm{l}$; Thermo Fisher Scientific, Inc.) was diluted in $50 \mu 1$ Opti-MEM, and they were incubated for $15 \mathrm{~min}$ at room temperature. Subsequently, the siRNA and Lipofectamine RNAiMAX solutions were mixed and incubated for $15 \mathrm{~min}$ at room temperature to allow complexes to form. The complexes were added to each well at a dilution of $1: 4$. Cells were incubated at $37^{\circ} \mathrm{C}$ in a humidified $5 \% \mathrm{CO}_{2}$ incubator for $24 \mathrm{~h}$ to induce gene knockdown. Following $24 \mathrm{~h}$ incubation with Opti-MEM medium the cells were used for experiments. The experiments were repeated three times.

Western blot analysis. Total protein was extracted from RAW264.7 cells (1x107 cells per sample) using the ReadyPrep Protein Extraction kit (Bio-Rad Laboratories, Inc., Hercules, CA, USA) and quantified by bicinchoninic acid assay. Proteins (40 $\mu \mathrm{g}$ per sample) were separated using a $12 \%$ SDS-PAGE and were transferred to nitrocellulose membranes using a Trans-Blot SD semi-dry electrophoresis transfer cell (Bio-Rad Laboratories, Inc.). Membranes were subsequently blocked at room temperature with 5\% skimmed milk for $2 \mathrm{~h}$ at room temperature. Then membranes were incubated with a rabbit-anti FFAR4 antibody $(1: 1,000)$ or rabbit-anti $\beta$-actin antibody $(1: 1,000)$ at $4^{\circ} \mathrm{C}$, overnight. Following three washes with TBS, the membranes were incubated with a horseradish 


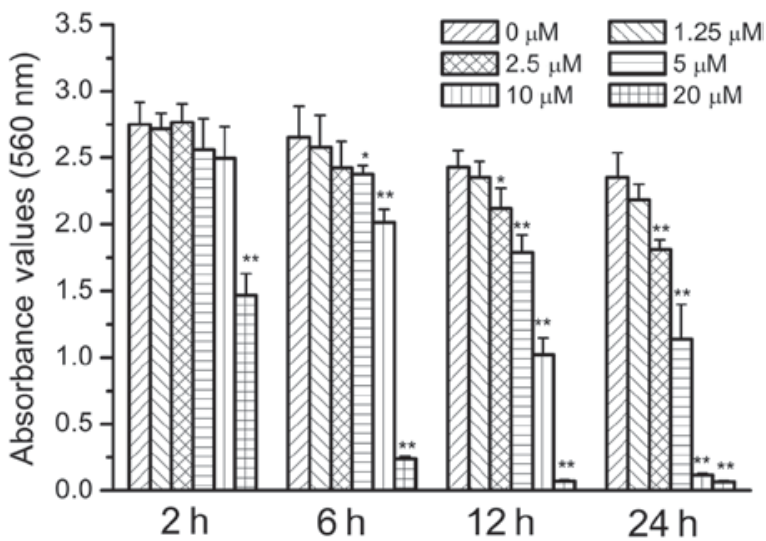

Figure 1. Effects of grifolic acid on RAW264.7 cell viability. Grifolic acid treatment inhibited the viability of RAW264.7 cells, in a dose- and time-dependent manner. $\mathrm{n}=24 ;{ }^{*} \mathrm{P}<0.05,{ }^{* *} \mathrm{P}<0.01$ vs. Control without grifolic acid.

peroxidase-conjugated goat-anti rabbit immunoglobulin $\mathrm{G}$ antibody (1:1,000; cat. no. 31460; Thermo Fisher Scientific, Inc.) for $1 \mathrm{~h}$ at room temperature. Following three washes with TBS, Clarity Max ${ }^{\mathrm{TM}}$ Western enhanced chemiluminescence Substrate (Bio-Rad Laboratories, Inc.) was added and membranes were incubated at room temperature for $4 \mathrm{~min}$. The luminescence from the membranes was imaged by a ChemiDoc MP gel imaging and analysis system (170-8280; Bio-Rad Laboratories, Inc.). The experiments were repeated three times.

Statistical analysis. Data are presented as the mean \pm standard error of the mean. Comparisons of means of multiple groups with each other or against one control group were analyzed with one-way analysis of variance followed by Bonferroni post-hoc test. $\mathrm{P}<0.05$ was considered to indicate a statistically significant difference.

\section{Results}

Effects of grifolic acid on RAW264.7 cell viability. Grifolic acid at $20 \mu \mathrm{mol} / 1$ significantly inhibited RAW264.7 cell viability at $2 \mathrm{~h}$ and led to almost total loss of cell viability following $6 \mathrm{~h}$ incubation $(\mathrm{P}<0.01)$. Observations were obtained at 2, 6, 12 and $24 \mathrm{~h}$ for each concentration following preliminary experiments, which demonstrated that these incubation lengths were optimal for use in the present study (data not shown). Grifolic acid at $10 \mu \mathrm{mol} / 1$ exhibited significant inhibition of viability following $6 \mathrm{~h}$ incubation and achieved maximal effects at $24 \mathrm{~h}$ $(\mathrm{P}<0.05)$. Grifolic acid at 5 and $2.5 \mu \mathrm{mol} / 1$ inhibited RAW264.7 cell viability from 6 and $12 \mathrm{~h}$, respectively and demonstrated significantly increased levels with the increased duration of incubation Treatment with grifolic acid at $1.25 \mu \mathrm{mol} / 1 \mathrm{did}$ not exhibit inhibitory effects at any time points investigated (Fig. 1).

Grifolic acid-treated RAW264.7 cell death. Based on the MTT assay results, at 10 and $20 \mu \mathrm{mol} / 1$ grifolic acid demonstrated more significant effects on RAW264.7 cells and were used in the experiments of Annexin V/PI staining. Observations were obtained at 2 and $6 \mathrm{~h}$ for each concentration following preliminary experiments, which demonstrated that longer incubations resulted in cell lysis whereas little effect was observed at shorter incubation times (data not shown). Grifolic acid $(20 \mu \mathrm{mol} / \mathrm{l})$ treatment for 2 or $6 \mathrm{~h}$ lead to a significant increase in the number of both Annexin V-and PI-staining positive RAW264.7 cells compared with the control cells that were not treated with grifolic acid $(\mathrm{P}<0.01$; Fig. 2A-D). Similarly, grifolic acid treatment at $10 \mu \mathrm{mol} / 1$ for 6 or $12 \mathrm{~h}$ also demonstrated a significant increase in the number of Annexin $\mathrm{V}$-FITC ${ }^{+} / \mathrm{PI}^{+}$cells compared with the control cells $(\mathrm{P}<0.01$; Fig. 2E).

Inhibition of ATP production by grifolic acid in RAW264.7 cells. The cellular ATP content in untreated control RAW264.7 cells was $32.31 \pm 5.32 \mathrm{nmol} / \mathrm{mg}$ protein. ATP content significantly reduced to $10.29 \pm 4.76 \mathrm{nmol} / \mathrm{mg}$ protein when cells were treated with $20 \mu \mathrm{mol} / 1$ grifolic acid for $2 \mathrm{~h}(\mathrm{P}<0.01)$. Grifolic acid treatment at $10 \mu \mathrm{mol} / 1$ for $2 \mathrm{~h}$ also significantly reduced cellular ATP content to $18.26 \pm 4.41 \mathrm{nmol} / \mathrm{mg}$ protein $(\mathrm{P}<0.01$; Fig. 3).

Effects of FFAR4 knockdown on grifolic acid-induced RAW264.7 cell death. Mouse FFAR4 siRNA transfection resulted in a notable reduction in FFAR4 protein expression level compared with the untransfected control cells (Fig. 4A). FFAR4 knockdown did not exhibit a significant influence on grifolic acid-induced inhibition of cell viability and apoptosis, as indicated by MTT assay and Annexin V-FITC/PI staining (Fig. 4B and C, respectively). Similarly, the decrease in cellular ATP content in grifolic acid-treated RAW264.7 cells was not affected by FFAR4-knockdown (Fig. 4D).

Effects of grifolic acid on MMP of RAW264.7 cells. JC-1 emits green fluorescence in the cytoplasm and exhibits membrane potential-dependent accumulation in mitochondria with a shift of emission wavelength from green to red $(10,11)$; MMP reduction is indicated by a decrease in the red/green fluorescence intensity ratio. In the present study, grifolic acid treatment resulted in a decrease in red/green fluorescence intensity ratio in a dose- and time-dependent manner (Fig. 5). Cells treated with $20 \mu \mathrm{mol} / 1$ grifolic acid exhibited a decrease in MMP at $5 \mathrm{~min}$, with the maximal effects achieved within $20 \mathrm{~min}$ (Fig. 5E). Grifolic acid treatment at $10 \mu \mathrm{mol} / 1$ significantly reduced MMP at $10 \mathrm{~min}$ and achieved the maximal effects in $40 \mathrm{~min}$ (Fig. 5E). MMP was also significantly decreased compared with the control $60 \mathrm{~min}$ following treatment with 5 and $2.5 \mu \mathrm{mol} / 1$ grifolic acid at 40 and $50 \mathrm{~min}$, respectively, but not with $1.25 \mu \mathrm{mol} / 1$ treatment (Fig. 5E).

Protective effects of cyclosporine A against grifolic acid-induced MMP loss and Raw264.7 cell death. Cyclosporine A is able to attenuate mitochondrial permeability transition and improve mitochondrial respiratory function $(12,13)$. Therefore, the effects of cyclosporine A on the grifolic acid-induced decrease in MMP were investigated. When RAW264.7 cells were pretreated with cyclosporine A at $20 \mu \mathrm{mol} / 1$ for $10 \mathrm{~min}$, grifolic acid-induced MMP loss was significantly attenuated compared with control cells that were treated with grifolic acid but not with cyclosporine A ( $\mathrm{P}<0.01$; Fig. 6A). Untreated control cells demonstrated no changes during measurement (data not shown). 

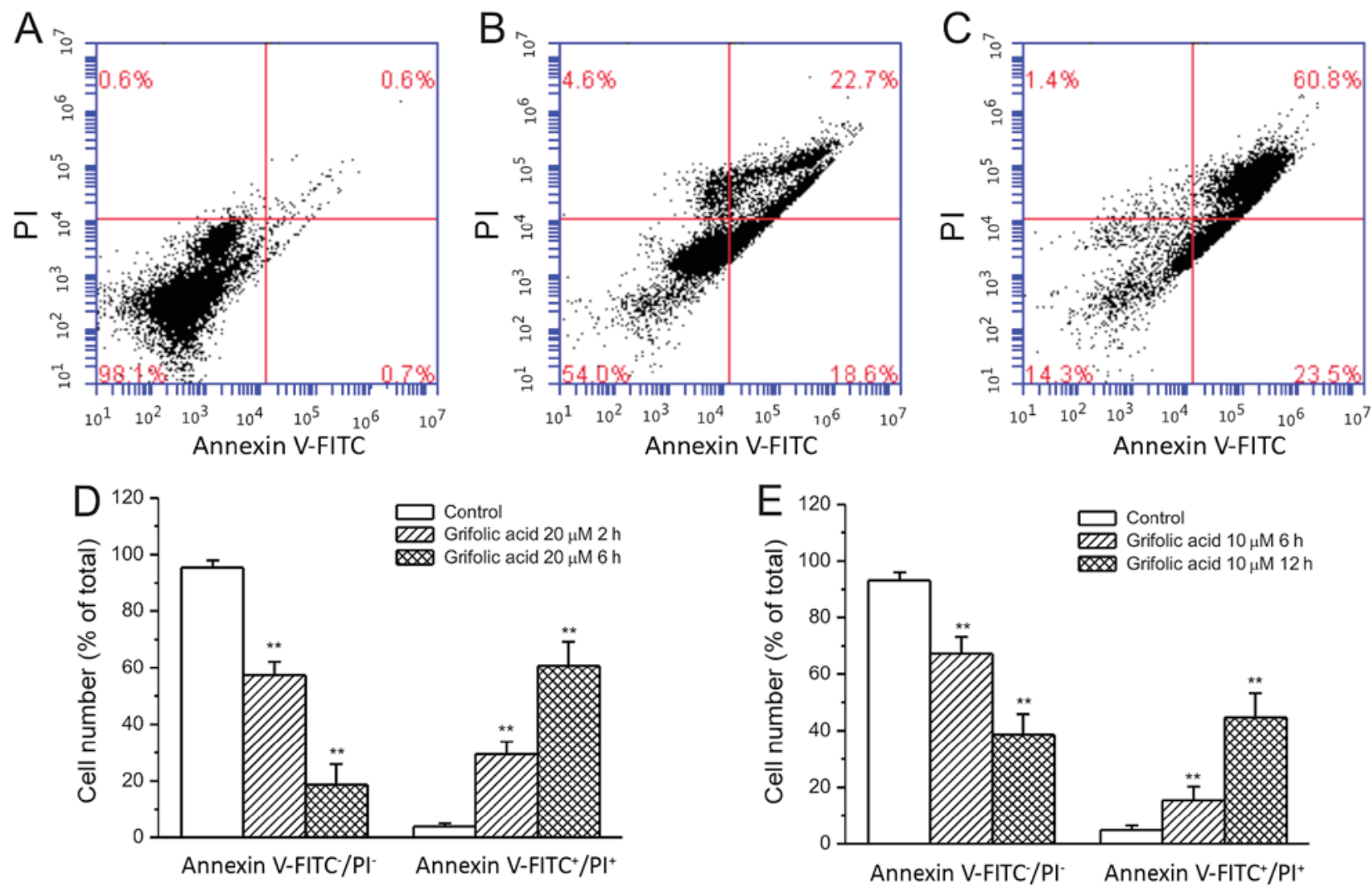

Figure 2. Grifolic acid-induced cell death in RAW264.7 cells. Grifolic acid treatment leads to a significant increase in the number of RAW264.7 cells that are positively stained with both Annexin V-FITC and PI. Representative results of flow cytometric analysis for the (A) control cells, (B) cells treated with $20 \mu \mathrm{mol} / 1 \mathrm{grifolic}$ acid for $2 \mathrm{~h}$ and (C) cells treated with $20 \mu \mathrm{mol} / 1$ grifolic acid for $6 \mathrm{~h}$ and (D) their quantification. (E) Cells treated with $10 \mu \mathrm{mol} / 1 \mathrm{grifolic}$ acid for 6 and $12 \mathrm{~h}$ also exhibited a significant increase in Annexin V-FITC ${ }^{+} / \mathrm{PI}^{+}$RAW264.7 cells compared with the control. $\mathrm{n}=5 ;{ }^{* *} \mathrm{P}<0.01$ vs. Control. FITC, fluorescein isothiocyanate; PI, propidium iodide.

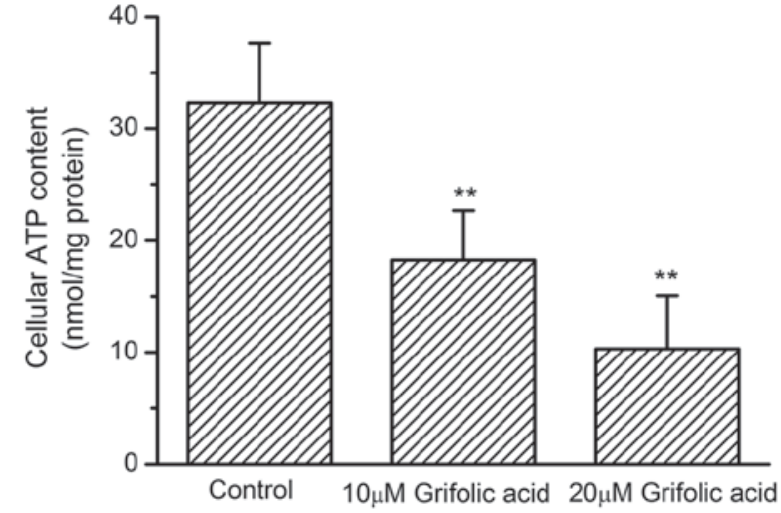

Figure 3. Effects of grifolic acid on cellular ATP content in RAW264.7 cells Cells treated with either 10 or $20 \mu \mathrm{mol} / 1$ grifolic acid for $2 \mathrm{~h}$ exhibited significant reductions in cellular ATP content. $n=12 ;{ }^{* *} \mathrm{P}<0.01$ vs. Control, $\mathrm{n}=12$. ATP, adenosine 5 ' triphosphate.

In addition, cyclosporine A treatment $(10 \mu \mathrm{mol} / \mathrm{l})$ also inhibited grifolic acid-induced decrease in cell viability of RAW264.7 cells (Fig. 6B).

\section{Discussion}

Grifolic acid was first extracted from the fresh fruiting bodies of the mushroom A. confluens, but little is known about its actions. Grifolic acid was previously demonstrated to activate
ERK and to increase intracellular calcium concentration in FFAR4-expressing cells though FFAR4 signaling (2). A number of other reports also revealed grifolic acid's actions on FFAR4 in FFAR4-expressing mouse intestinal STC-1 cells and $\mathrm{K}$ cells that secrete GIP. Grifolic acid was also used to antagonize the effects of FFAs on FFAR4 (7). Therefore, grifolic acid is considered as an agonist or antagonist for FFAR4. FFAR4 is expressed in macrophages including RAW264.7 cells (14). Results from the present study demonstrated that grifolic acid treatment induced mouse RAW264.7 macrophage apoptosis. However, the effects of grifolic acid on cell death were unaltered by the inhibition of FFAR4 expression in RAW264.7 cells. Therefore, the present study suggested that grifolic acid is not a pure FFAR4 agonist or antagonist, and may have additional pharmacological targets to inhibit cell viability.

The effects of grifolic acid to induce RAW264.7 cell death may be due to the decrease in ATP production following damage to mitochondrial functions. Grifolic acid-treated RAW264.7 cells exhibited a significant increase in the percentage of Annexin V-FITC/PI double-positive cells, which indicated necrosis or late stage of apoptosis, but this needs to be confirmed. It is known that cellular ATP levels influence cell viability $(15,16)$. Cellular ATP reduction leads to cell death, and the rate and speed of ATP reduction determines the type of cell death (17). A slow reduction of ATP levels leads to cell apoptosis, whereas rapid reduction of ATP results in cell swelling and necrosis $(15,18,19)$. Grifolic acid induced a 

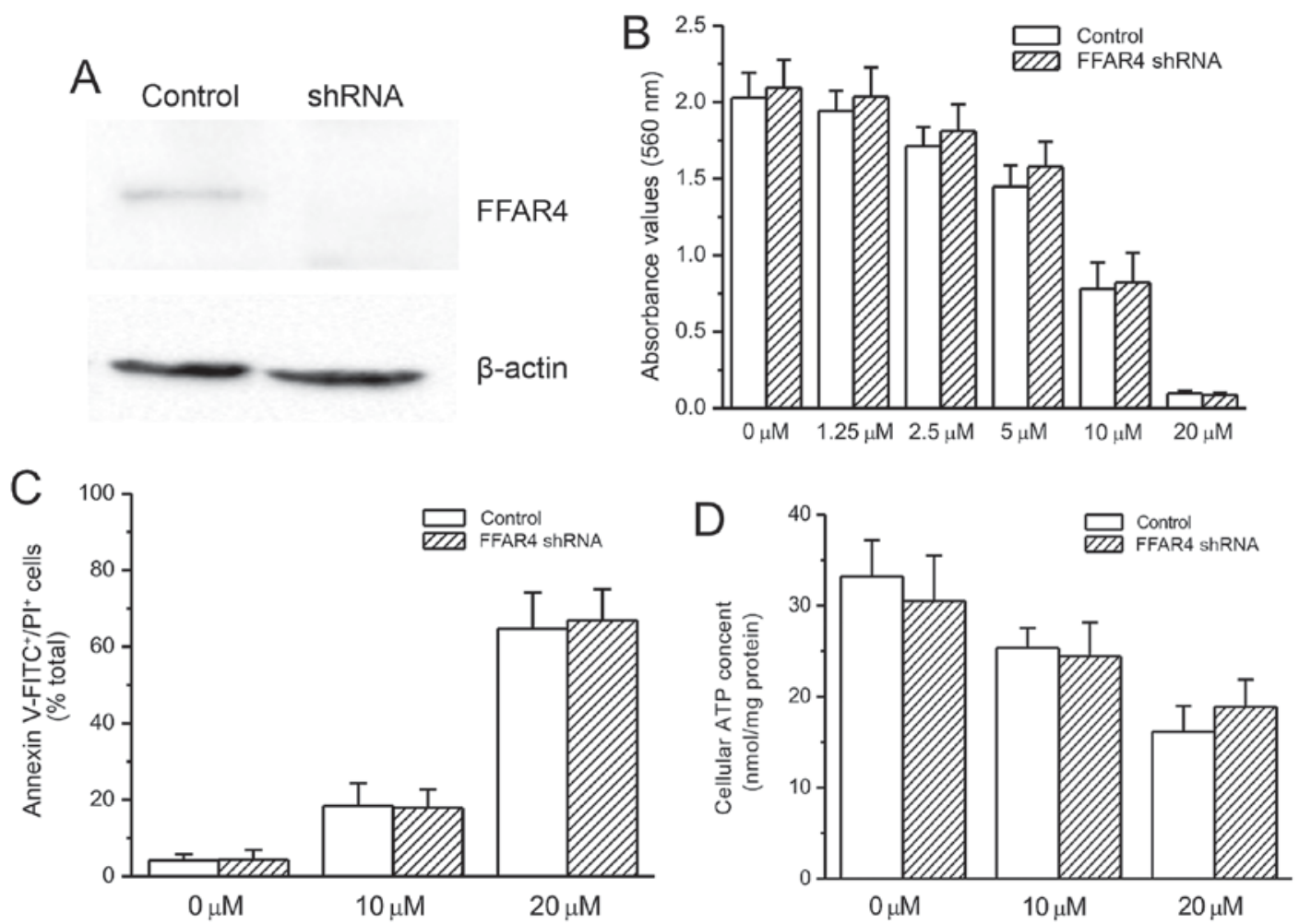

Figure 4. Effects of FFAR4 knockdown on grifolic acid-induced RAW264.7 cell death. (A) Knockdown of FFAR4 expression following siRNA transfection, as indicated by western blotting. (B) FFAR4-siRNA transfection did not affect the grifolic acid treatment-reduced cell viability. (C) Grifolic acid-induced increase in Annexin V-FITC $/ \mathrm{PI}^{+}$double-staining (late apoptosis/necrosis) was not affected by FFAR4 knockdown. (D) Grifolic acid treatment at either 10 or $20 \mu \mathrm{mol} / 1$ for $2 \mathrm{~h}$ reduced cellular ATP content with no significant difference observed between FFAR4 knockdown and control cells. ATP, adenosine triphosphate; FITC, fluorescein isothiocyanate; FFAR4, free fatty acid receptor 4; PI, propidium iodide.

decrease in ATP levels in $2 \mathrm{~h}$ in RAW264.7 cells, which may lead to cell necrosis.

Mitochondria are the cell organelles responsible for ATP production (20). To function under physiological conditions, mitochondria need to maintain MMP; a reduction in MMP may lead to functional damage of mitochondria and may result in deficiency of ATP production (21). In the present study, it was demonstrated that grifolic acid significantly reduced MMP of RAW264.7 cells in a dose- and time-dependent manner, which is in accordance with the effects of grifolic acid on RAW264.7 cell death. This is the first study, to the best of the authors' knowledge, to demonstrate the influence of grifolic acid on mitochondria, which indicated that mitochondria may be a target of grifolic acid. The improvement of grifolic acid-induced reduction of MMP and cell death by cyclosporine A further supported the observation that grifolic acid affected mitochondrial function. Mitochondria form permeability transition pores on the membrane under certain pathological conditions, which reduce MMP and lead to a release of cell death regulators $(22,23)$. Cyclosporine A may prevent the formation of permeability transition pores on the mitochondrial membrane by acting on cyclosporine A-binding protein in mitochondria (24-27). Cyclosporine A treatment significantly attenuated the grifolic acid-induced decrease in MMP and protected RAW264.7 cells against grifolic acid-induced cell death. The attenuation of grifolic acid-induced MMP reduction by cyclosporine A, the mitochondria protector, further indicated that mitochondria may be the target of grifolic acid. In conclusion, grifolic acid exposure damaged mitochondrial function, which resulted in MMP reduction and led to the decrease in ATP production causing RAW264.7 cell death.

The effects of grifolic acid on RAW264.7 cell death appear to be independent of FFAR4. FFAR4 is expressed in macrophages such as RAW264.7 cells, and its activation serves an anti-inflammatory role in macrophages $(8,28,29)$. In the present study, FFAR4 expression was successfully inhibited as confirmed by western blot. Knockdown of FFAR4 did not demonstrate any influence on grifolic acid-induced cell death and MMP reduction. Therefore, FFAR4 may not take part in the action of grifolic acid causing RAW264.7 cell death. The molecular mechanism of grifolic acid-induced damage to mitochondria remains unknown and needs to be clarified in the future.

In summary, grifolic acid treatment reduced MMP and ATP production and led to RAW264.7 cell death. Considering that the concentration of grifolic acid used in the present study was within the same range as what was used to activate FFAR4 (2,6,7,30), it was suggested that grifolic acid may not be a pure FFAR4 agonist. Other pharmacological target for grifolic acid that links grifolic acid to cell mitochondria dysfunction remains to be clarified.

\section{Acknowledgements}

The present study was supported by the grants from Shaanxi Province (grant no. 2015KTCQ03-03) and Xi'an Medical University (grant no. 2015RCYJ02). 
A

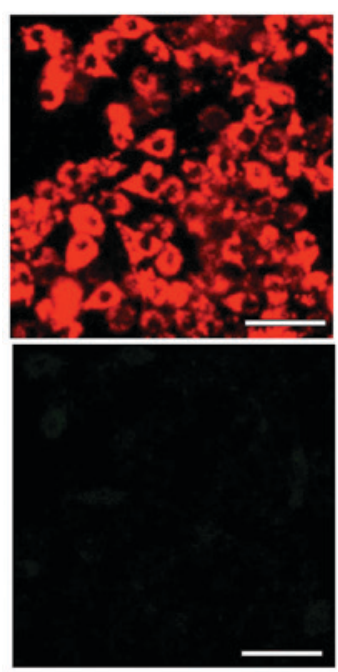

B
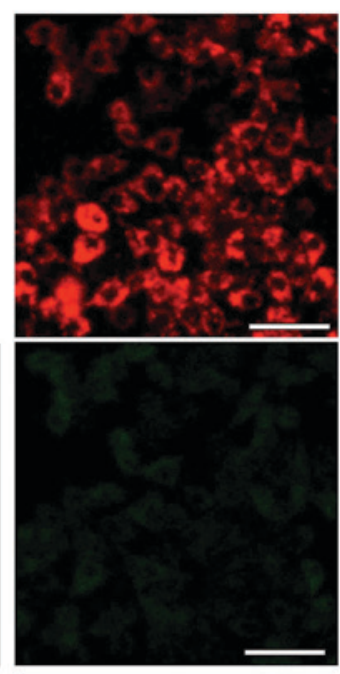

C
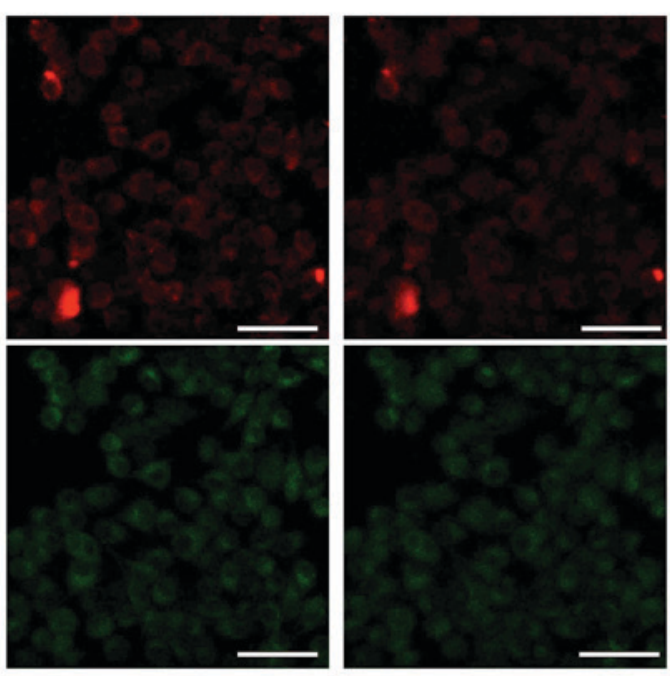

$\mathrm{E}$

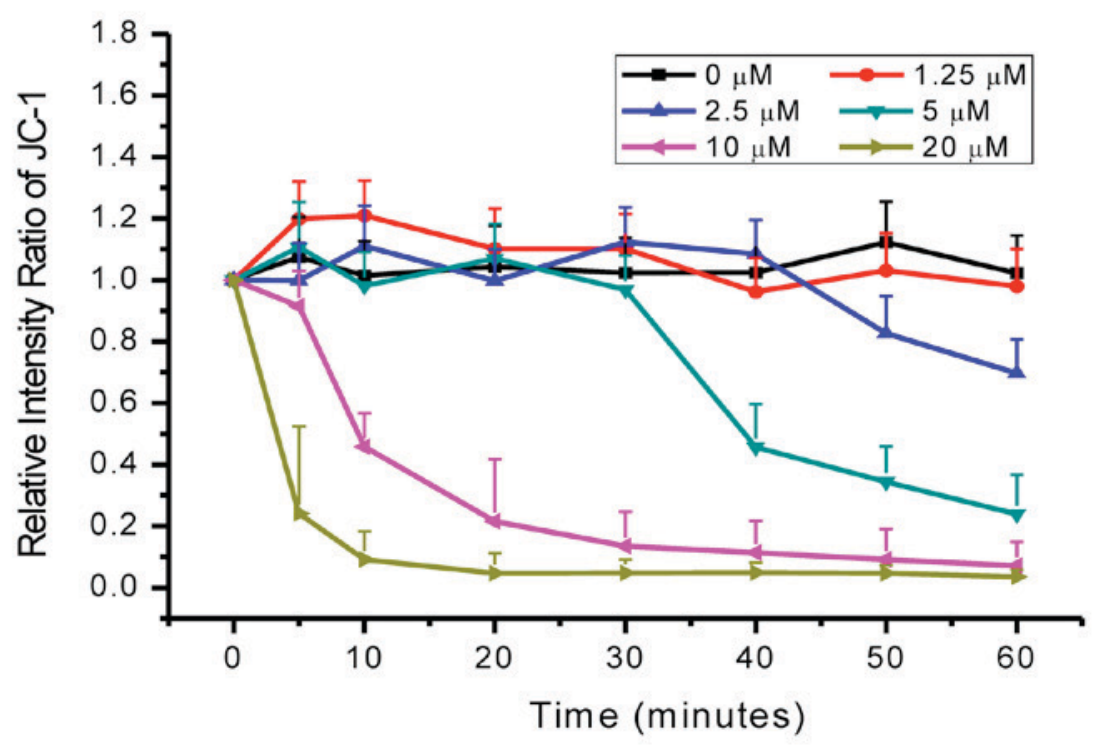

Figure 5. Effects of grifolic acid on MMP in RAW264.7 cells. The cellular intensity of MMP indicator JC-1 in (A) control and following $20 \mu \mathrm{mol} / 1$ grifolic acid treatment for (B) 5, (C) 10 and (D) 20 min in a continuous observation. (E) Statistical analysis of red/green fluorescence intensity ratio in each cell. $\mathrm{n}=100$. MMP, mitochondrial membrane potential.
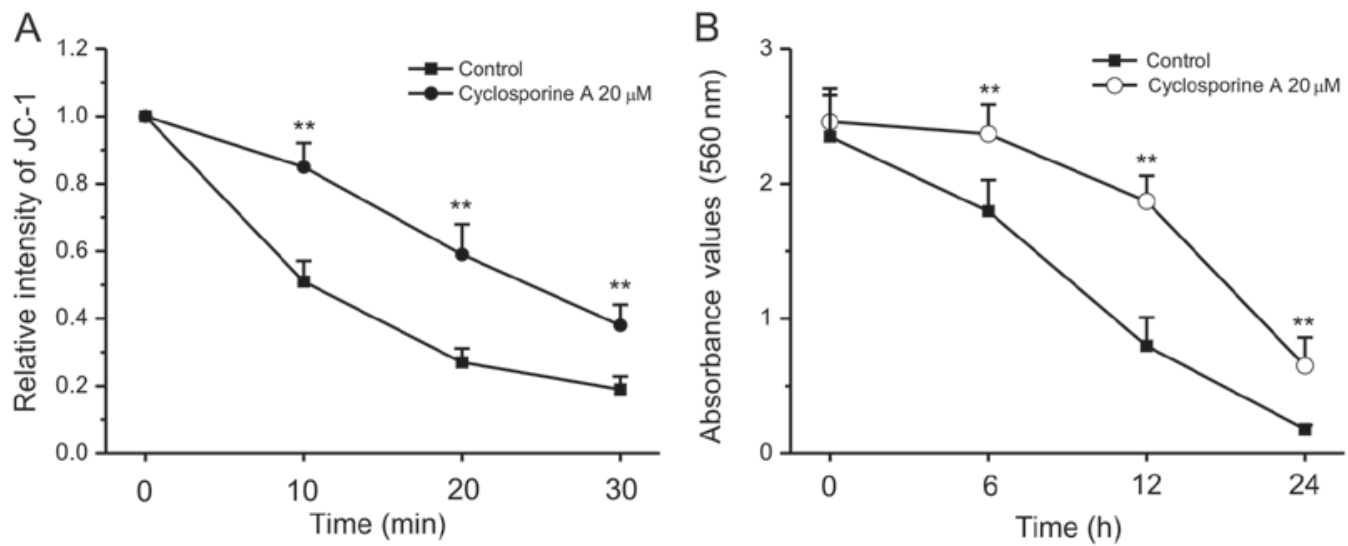

Figure 6. Effects of cyclosporine A treatment on grifolic acid-induced MMP reduction and cell viability in RAW264.7 cells. (A) Cyclosporine A inhibited grifolic acid-induced decreases of MMP of RAW264.7 cells. $n=60 ;{ }^{* *} \mathrm{P}<0.01$ vs. the group treated with grifolic acid alone. (B) Cyclosporine A inhibited grifolic acid-induced reduction of cell viability. $n=24 ;{ }^{* *} \mathrm{P}<0.01$ vs. the group treated with grifolic acid alone. MMP, mitochondrial membrane potential. 


\section{References}

1. Mobraten K, Haug TM, Kleiveland CR and Lea T: Omega-3 and omega-6 PUFAs induce the same GPR120-mediated signalling events, but with different kinetics and intensity in Caco-2 cells Lipids Health Dis 12: 101, 2013.

2. Hara T, Hirasawa A, Sun Q, Sadakane K, Itsubo C, Iga T, Adachi T, Koshimizu TA, Hashimoto T, Asakawa Y and Tsujimoto G: Nove selective ligands for free fatty acid receptors GPR120 and GPR40. Naunyn Schmiedebergs Arch Pharmacol 380: 247-255, 2009.

3. Liu HD, Wang WB, Xu ZG, Liu CH, He DF, Du LP, Li MY, Yu X and Sun JP: FFA4 receptor (GPR120): A hot target for the development of anti-diabetic therapies. Eur J Pharmacol 763: $160-168,2015$.

4. Sun Q, Hirasawa A, Hara T, Kimura I, Adachi T, Awaji T, Ishiguro M, Suzuki T, Miyata N and Tsujimoto G: Structure-activity relationships of GPR120 agonists based on a docking simulation. Mol Pharmacol 78: 804-810, 2010.

5. Shimpukade B, Hudson BD, Hovgaard CK, Milligan G and Ulven T: Discovery of a potent and selective GPR120 agonist. J Med Chem 55: 4511-4515, 2012.

6. Li AJ, Wang Q, Dinh TT, Simasko SM and Ritter S: Mercaptoacetate blocks fatty acid-induced GLP-1 secretion in male rats by directly antagonizing GPR40 fatty acid receptors. Am J Physiol Regul Integr Comp Physiol 310: R724-R732, 2016.

7. Iwasaki K, Harada N, Sasaki K, Yamane S, Iida K, Suzuki K, Hamasaki A, Nasteska D, Shibue K, Joo E, et al: Free fatty acid receptor GPR120 is highly expressed in enteroendocrine $\mathrm{K}$ cells of the upper small intestine and has a critical role in GIP secretion after fat ingestion. Endocrinology 156: 837-846, 2015.

8. Oh DY, Talukdar S, Bae EJ, Imamura T, Morinaga H, Fan W, Li P, Lu WJ, Watkins SM and Olefsky JM: GPR120 is an omega-3 fatty acid receptor mediating potent anti-inflammatory and insulin-sensitizing effects. Cell 142: 687-698, 2010.

9. Liu Y, Chen LY, Sokolowska M, Eberlein M, Alsaaty S, Martinez-Anton A, Logun C, Qi HY and Shelhamer JH: The fish oil ingredient, docosahexaenoic acid, activates cytosolic phospholipase $A_{2}$ via GPR120 receptor to produce prostaglandin $\mathrm{E}_{2}$ and plays an anti-inflammatory role in macrophages. Immunology 143: 81-95, 2014.

10. Reers M, Smith TW and Chen LB: J-aggregate formation of a carbocyanine as a quantitative fluorescent indicator of membrane potential. Biochemistry 30: 4480-4486, 1991

11. Smiley ST, Reers M, Mottola-Hartshorn C, Lin M, Chen A, Smith TW, Steele GD Jr and Chen LB: Intracellular heterogeneity in mitochondrial membrane potentials revealed by a J-aggregate-forming lipophilic cation JC-1. Proc Natl Acad Sci USA 88: 3671-3675, 1991 .

12. Novgorodov SA, Gudz TI, Kushnareva YE, Zorov DB and Kudrjashov YB: Effect of ADP/ATP antiporter conformational state on the suppression of the nonspecific permeability of the inner mitochondrial membrane by cyclosporine A. FEBS Lett 277: 123-126, 1990.

13. Yu W, Zhang X, Liu J, Wang X, Li S, Liu R, Liao N, Zhang T and Hai C: Cyclosporine a suppressed glucose oxidase induced P53 mitochondrial translocation and hepatic cell apoptosis through blocking mitochondrial permeability transition. Int J Biol Sci 12 : 198-209, 2016
14. Han L, Song S, Niu Y, Meng M and Wang C: Eicosapentaenoic acid (EPA) induced macrophages activation through GPR120-mediated Raf-ERK1/2-IKK $\beta-N F-\kappa B$ p65 signaling pathways. Nutrients 9: pii: E937, 2017.

15. Leist M, Single B, Castoldi AF, Kühnle S and Nicotera P: Intracellular adenosine triphosphate (ATP) concentration: A switch in the decision between apoptosis and necrosis. J Exp Med 185: 1481-1486, 1997.

16. Nicotera $\mathrm{P}$ and Leist M: Energy supply and the shape of death in neurons and lymphoid cells. Cell Death Differ 4: 435-442, 1997.

17. Skulachev VP: Bioenergetic aspects of apoptosis, necrosis and mitoptosis. Apoptosis 11: 473-485, 2006.

18. Nicotera P, Leist M and Ferrando-May E: Intracellular ATP, a switch in the decision between apoptosis and necrosis. Toxicol Lett 102-103: 139-142, 1998.

19. Eguchi Y, Srinivasan A, Tomaselli KJ, Shimizu S and Tsujimoto Y: ATP-dependent steps in apoptotic signal transduction. Cancer Res 59: 2174-2181, 1999.

20. Ernster L and Schatz G: Mitochondria: A historical review. J Cell Biol 91: 227s-255s, 1981.

21. Kadenbach B, Ramzan R, Moosdorf R and Vogt S: The role of mitochondrial membrane potential in ischemic heart failure. Mitochondrion 11: 700-706, 2011.

22. Lemasters JJ, Qian T, He L, Kim JS, Elmore SP, Cascio WE and Brenner DA: Role of mitochondrial inner membrane permeabilization in necrotic cell death, apoptosis, and autophagy. Antioxid Redox Signal 4: 769-781, 2002.

23. Nakagawa Y, Suzuki T, Kamimura H and Nagai F: Role of mitochondrial membrane permeability transition in $\mathrm{N}$-nitrosofenfluramine-induced cell injury in rat hepatocytes. Eur J Pharmacol 529: 33-39, 2006.

24. Plin C, Haddad PS, Tillement JP, Elimadi A and Morin D: Protection by cyclosporin A of mitochondrial and cellular functions during a cold preservation-warm reperfusion of rat liver. Eur J Pharmacol 495: 111-118, 2004

25. Onishi A, Miyamae M, Kaneda K, Kotani J and Figueredo VM: Direct evidence for inhibition of mitochondrial permeability transition pore opening by sevoflurane preconditioning in cardiomyocytes: Comparison with cyclosporine A. Eur J Pharmacol 675: 40-46, 2012.

26. Andreeva L, Tanveer A and Crompton M: Evidence for the involvement of a membrane-associated cyclosporin-A-binding protein in the $\mathrm{Ca}(2+)$-activated inner membrane pore of heart mitochondria. Eur J Biochem 230: 1125-1132, 1995.

27. Halestrap AP, Connern CP, Griffiths EJ and Kerr PM: Cyclosporin A binding to mitochondrial cyclophilin inhibits the permeability transition pore and protects hearts from ischaemia/reperfusion injury. Mol Cell Biochem 174: 167-172, 1997.

28. Oh DY, Walenta E, Akiyama TE, Lagakos WS, Lackey D, Pessentheiner AR, Sasik R, Hah N, Chi TJ, Cox JM, et al: A Gpr120-selective agonist improves insulin resistance and chronic inflammation in obese mice. Nat Med 20: 942-947, 2014.

29. Im DS: Functions of omega-3 fatty acids and FFA4 (GPR120) in macrophages. Eur J Pharmacol 785: 36-43, 2016.

30. Janssen S, Laermans J, Iwakura H, Tack J and Depoortere I: Sensing of fatty acids for octanoylation of ghrelin involves a gustatory G-protein. PLoS One 7: e40168, 2012. 